\title{
Neuromarketing: Applications, Challenges and Promises
}

\author{
Pravin Raj Solomon* \\ Department of Biotechnology, India
}

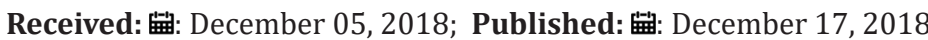

*Corresponding author: Pravin Raj Solomon, School of Chemical and Biotechnology, Tirumalaisamudram, Thanjavur, India

\begin{abstract}
Neuromarketing is a field of marketing research that studies consumers' sensorimotor, cognitive, and affective response to marketing stimuli. Consultative selling suggests that a customer's shopping experience is managed by the salesperson's behaviour and in-store marketing assets, and that the customer gets engaged step by step. The field of neuromarketing provides excellent avenues for reading the consumers mind, interest, preferences and thereby enable the marketers to perform effective targeted marketing. The technology offers a direct peak into the decision-making centres of the brain thereby can positively impact upon the decision-making process towards buying a product.

Neuromarketing employs several techniques and tools for analysis of inside \outside reflexes of the consumer's brain and it avails the latest cognitive scanning techniques for analysis. Some of the technology infused neuromarketing inside reflex techniques used includes EEG, MEG, fMRI, PET, Galvanic skin response, TMS, electromyography and cardiovascular parameters. Besides there are also several time-tested conventional techniques of outside reflex detection techniques such as body language, emphatic design, facial coding, eye tracking is also employed in neuromarketing. The concept of neuromarketing is bound to make a deep impact in the emerging economies like India with their rapidly increasing consumer population and consumer buying potential.
\end{abstract}

\section{Introduction}

Neuromarketing is a marketing strategy connecting to the subconscious, emotional aspect of the customer and aims to create an unbreakable bond with the customer and the product. It is an interdisciplinary field combining aspects of neuroscience, psychology and marketing. The cornerstone of neuromarketing is to assess the consumer's cognitive and emotional reaction to the various marketing techniques [1]. The term "neuroculture" denotes the allied fields of neurobiology. Neuroculture is the genesis of new avenues in science such as neurophilosophy neuroethology, a hybrid of neuroscience with other fields of science and humanities [2]. The term neuromarketing was popularised in 2002 by the market research companies. Two market research companies from USA namely Bright house and Sales Brain invented the usage of knowledge from cognition in the field of market research. This introduced a new dimension in the field of market research. The primary idea of neuromarketing is looking at the consumer's behaviour from a cognitive angle. In 2004, Read Montague from Baylor College of Medicine scanned the brains of people drinking either Pepsi or Coca cola using the fMRI technique.
The results showed increased brain activity in subjects when they are consciously aware of the brand they were drinking. The consumption of the favourite brand showed increased activity in the frontal cortex of the brain. The frontal cortex region of the brain is involved in attention to detail, short term memory and decisionmaking processes. This is the first experimental proof of the role of the emotional attachment of the brain with brand popularity and the importance of neuromarketing as a credible marketing tool.

\section{Importance of Neuromarketing}

As the famous saying goes "marketing is no longer about the products that we make but about the stories we tell". The stories reaching the consumers through advertisements and soliciting must create an emotional chord between the product and the consumers. Traditionally marketers and advertisers have used different methods of advertisements and product development initiatives. This involves huge monetary inputs and time duration that never found its way to people's memory bank and persuades their decision making. Neuroimaging and neuromarketing strategies emerge as a prominent and viable alternative that 
can tweak the next generation of smart customers and highly competitive consumer market. Neuromarketing technique is the latest and advanced tool used by marketing researchers to study and understand the consumer behaviour patterns [3]. Neuromarketing uses cutting edge techniques in brain scanning to understand the nuances behind the psychological decision-making process of the customer [4].

Measurement of the brainwaves may ideally reveal consumers' subconscious responses to marketing stimuli [5-9]. By Neuromarketing one can positively single out the element of an advertisement that creates a feel-good effect in the minds and memories of the customer [10-12]. This can help with the selection and timing of visual and audio features for an effective advertisement [11]. This will affirmatively help in the creation of brands, brand research and its effect on decision-making process of the customer [13]. Neuromarketing opens avenues to study and identify the causes of compulsive purchasing disorders and offers its potential use in effective marketing [10,11,14,15]. Neuromarketing is a unique technique than can procure information above and beyond the level of human cognition and perception because purchasing is largely a subconscious process [8,11,13,16-18].

\section{Methods Followed}

The primary aim of the paper is to analyse the importance of neuromarketing and its benefits in the field of marketing from previous research papers and articles. The critical review of the various techniques of neuromarketing and their benefits on the various market input tools are analysed in length. The influence of the various techniques and mechanisms of neuromarketing and its impact on proven marketing success stories are gleaned from the available literature and studies. The advantages, limitations, ethical implications and future prospects of neuromarketing are discussed sufficiently.

\section{Human Brain and its Function}

Brain is a three-pound organ that controls all functions of the body. It controls intelligence, creativity, emotion, and memory. Brain receives information through five senses namely sight, smell, touch, taste and hearing. It accepts and processes the information and stores it for future use in our memory. The cerebrum is the prominent part of the brain. The cerebrum has two distinct hemispheres. Each hemisphere has frontal, temporal, parietal, and occipital lobe. Frontal lobe plays a role in behaviour, emotions, Judgment, planning and problem solving. Parietal lobe Interprets signals from vision, hearing, motor, sensory and memory. Temporal lobe enables understanding of language (Wernicke's area) and memory.

\section{Neuronal Coding and Memory}

Memory comprises three processes namely encoding, storing and decoding (Figure 1). Different areas of the brain are involved in memory depending on the type of memory. Short-term memory is stored in the prefrontal cortex and lasts for about a minute. Long-term memory is processed in the hippocampus region of the temporal lobe and stores information for long time. The typical brain is made up of nerve cells (neurons) and glial cells. The neuron functions primarily by electrical and chemical signals. Neurons transmit information by tiny gaps called synapse. A neuron has multiple arms called dendrites. They act like antennae picking up messages from other nerve cells. The information reaching the brain are converted into codes and stored in memory called encoding. The information from the memory is recollected by decoding. Neural code is for the brain as binary code is to the computers. The various models of neural coding are depicted in Figure 2. The challenge of neuromarketing is to hypnotise and tweak the neural code towards decision making for buying a product.

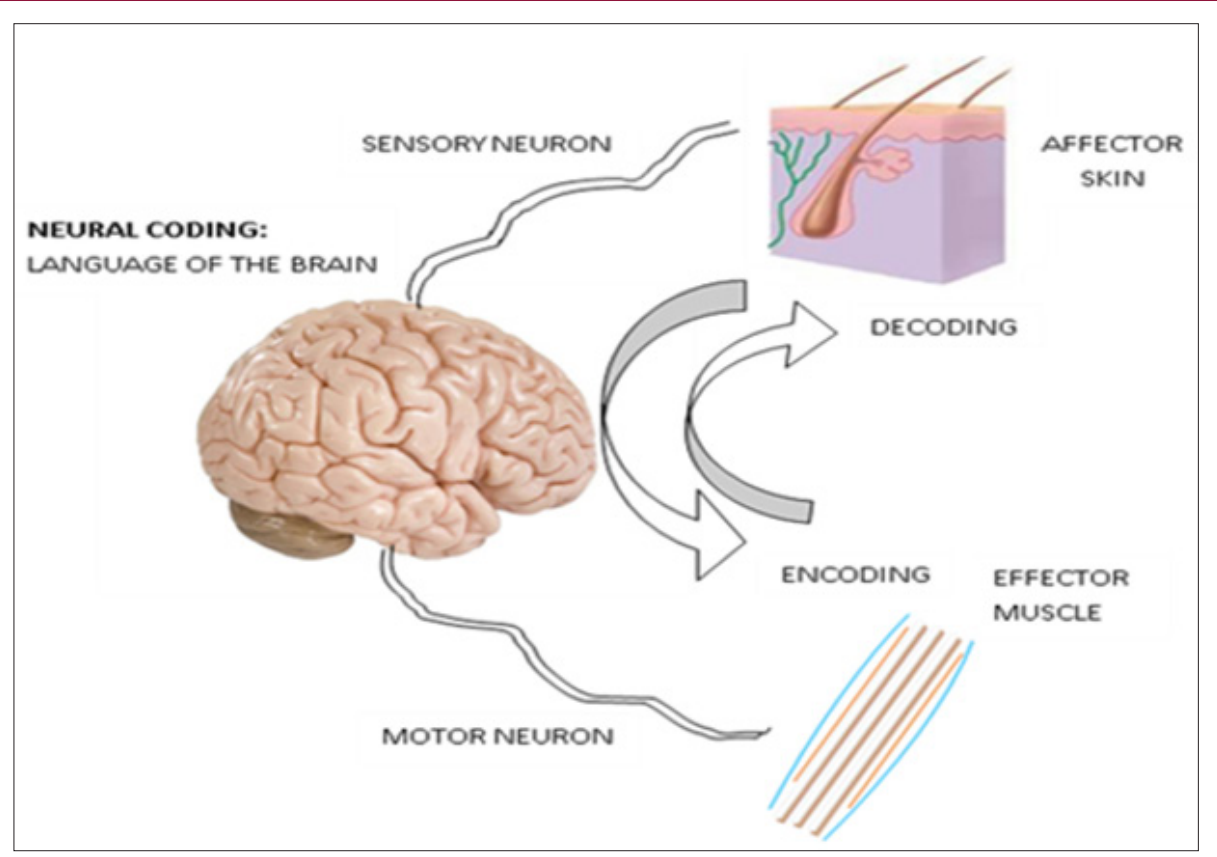

Figure 1: The direction of the neural coding aspects of encoding and decoding shown. 


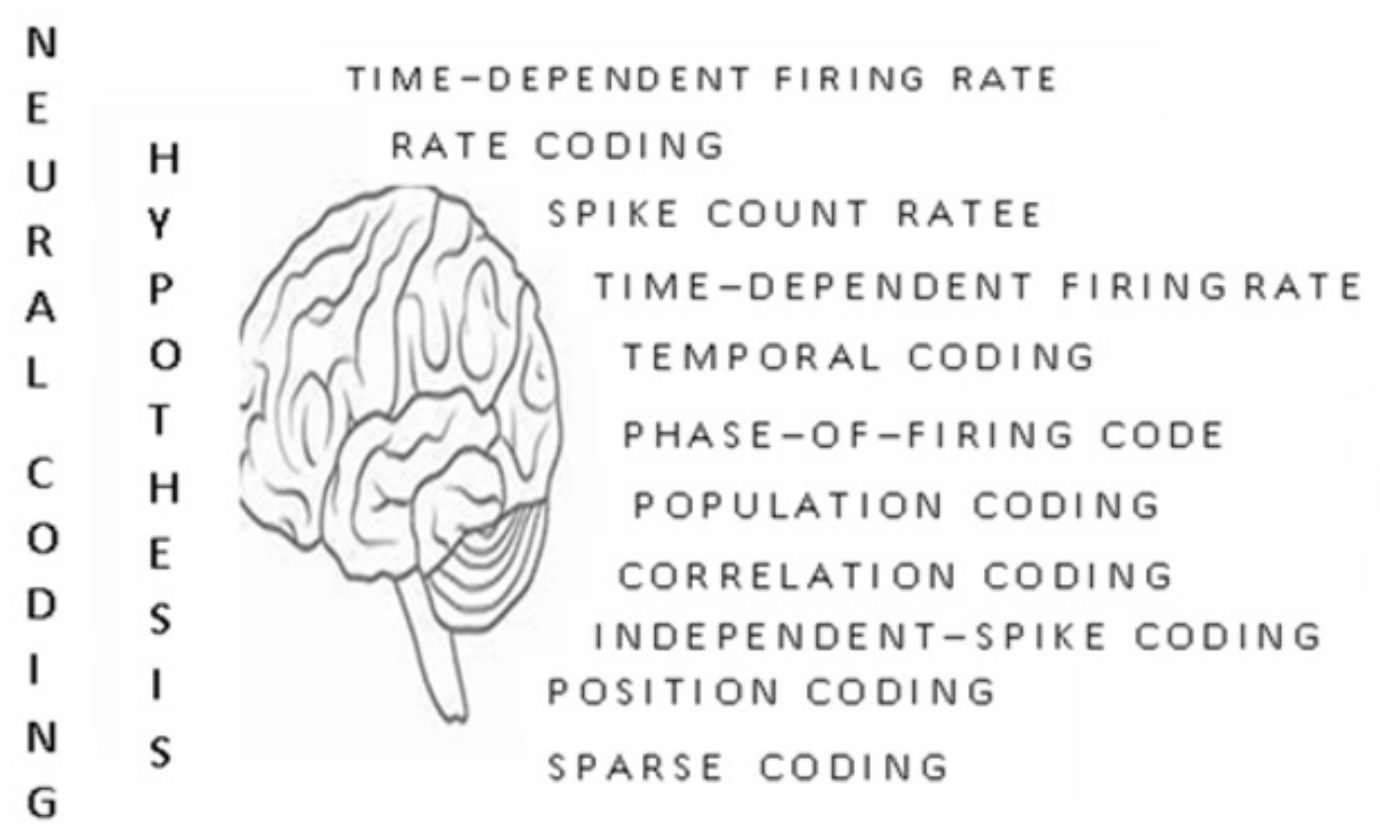

Figure 2: The prominent models of neural coding.

\section{Techniques of Neuromarketing}

\section{Outside Reflex}

Prominent outside reflex method includes body language, empathic design, facial coding and eye (Figure 3). They comprise the classical methods for collection of information about the brain.
They perceive the outside reflexes that originate in the brain. A lie detector measures the outside reflexes. Outside reflex includes aspects of emotional response such as sweat and goose bumps. The reason for emotional stimulus can also originate from reasons other than lying making this method unreliable [19].

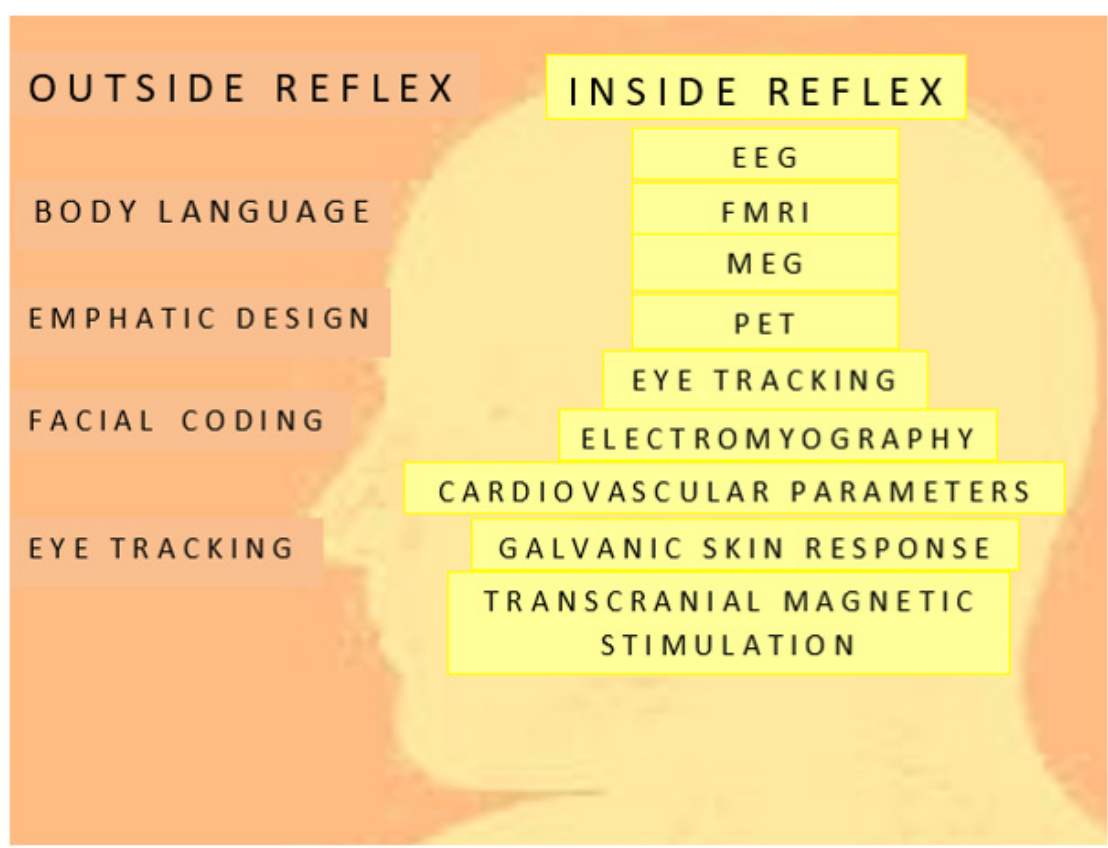

Figure 3: Prominent outside and inside reflex techniques of neuromarketing.

\section{Body Language}

Body language offers a window to detect brain emotions similarly to a fMRI scanner. Body language expression includes non-verbal emotions and communicational cues expressed by contraction and relaxation of muscles. It also includes conscious and unconscious gestures, body movements and body posture.

\section{Empathic Design}

A prominent method for analysing human beings without any device is called empathic design. Sensitive observation is made 
on the customer's daily routine without their knowledge [20]. Keen observation is made on the usage of a particular product by a test person in its natural environment. The process of gleaning information instead of asking a person and applying the knowledge in marketing is known as direct-marketing-principle $[19,20]$.

\section{Facial Coding}

Facial coding recognises, and patterns facial expressions associated with human emotions. A total of 24 muscle movement combinations are identified with seven basic human emotions. Path breaking studies in facial coding are done by leading facial coding researcher Dan Hill. Specific stimulus and their linked facial express patterns are identified, deciphered and practically applied in marketing.

\section{Eye Tracking}

Another important outside reflex is the eye-tracking method. Eye tracking reveals information about the subconscious brain reflex to stimulus and activity. This method is highly reliable. The information from eye tracking can be effectively used in the designing of commercials and web pages. It enables market researchers to track the finer details of consumer's attention and preference. The sequential choice of preference can be determined as well.

\section{Input-/Output Models}

This method accesses the brain activity by analysing the pattern of result to certain stimulus. In the Input/output Model the brain is considered as a black box. This method works on the principle there is always a measurable output to any marketing stimulus [19].

\section{Inside Reflexes}

Inside reflex approach peeks inside the brain. It is done by using a range of techniques involving brain scans (Figure 3). Inside reflexes differ from input-/output model basically in application. The impact of inside reflex in advertising is primarily in packaging. Inside reflex determines the emotional attachment to a product and the psychological impact on a prospective customer during the course of an advertisement.

\section{EEG}

EEG stands for Electroencephalography. The technique is an electrical representation of the brain activity. This technique is ideal to detect changes in the electrical field associated with specific areas of the brain $[5,8,21,22]$. EEG uses electrodes to record electronic signals of brain activity $[8,5,19,22]$. The electrodes can be attached to the skull. It can make recordings of around 40 minutes. Neurons are the cells involved in cognitive response. There are around trillions of synapses associated with cognition [8]. Helmet or cap attached with electrodes is put on an individual's head followed by presentation of products and services. The relative attractiveness of a product to the customer can be quantified from the brain activity $[8,19]$. EEG can detect short neural activity since its temporal resolution is in milliseconds. [5,21]. Instrument to measure EEG is light and portable [22]. The primary disadvantage of EEG is the interference from noise or unwanted electronic activity from brain [19]. Another problem is imprecise spatial resolution (approximately one centimetre). This can be overcome by attaching a greater number of electrodes to the skull $[5,8,21]$.

\section{fMRI}

Functional Magnetic Resonance Imaging is a tool to study the anatomic structure of the brain by detecting the blood flow [19]. MRI scan is for detecting blood oxygen levels [5]. The increase in neural activity of a brain area indicates the presence of oxygen-rich blood in that area. Functional MRI (fMRI) is a neuromarketing tool for investigating differences in brain activity between different regions of the brain [19,22-24]. The oxygenated and deoxygenated blood create different magnetic waves. This difference can be identified in the form of signals [21]. Initially an fMRI brain scan made at rest condition with no stimulus and used as baseline [25]. The advertisement stimulus increases the oxygenated blood to certain regions of the brain $[8,26]$. This is measured and compared with the baseline to detect the extent of activation by the advertisement stimulus.

\section{MEG}

The Magneto Encephalography is a non-invasive procedure to investigate neural activity. MEG directly measures the magnetic field created by the neural activity. This is in contrast to the EEG that conducts voltage fluctuations. The spatial and temporal intensity of brain activity among the different regions of the brain can be measured by MEG [27]. MEG offers increased spatial resolution, but the advantage is offset by its high cost [8].

\section{PET}

Positron Emission Tomography Technique has similar efficiency and spatial resolution like fMRI. The technique requires mild exposure to radioactive particles (positrons) for obtaining results. The health hazard associated with PET makes it highly undesirable and less attractive for use as a neuromarketing tool [28].

\section{Eye Tracking}

Eye tracking aims to identify the primary focus area of consumer's visual attention, response to visual cues, attention span, gaze patterns and pupil adjustments. The main advantage is the portability of the equipment. The primary disadvantage is lack of association of emotions with different areas of the brain. Eye tracking determines the time duration spend on focusing, object focussed, pupil behaviour, frequency of observation in response to the presented stimuli etc [29]. The eye tracking determines both fixed and interrupted eye movement.

\section{Facial Recognition or Electromyography}

Electromyography detects the various facial expressions that reflect the mental status of a person. Tiny facial muscular movements imperceptible to naked eye is measured by electrodes attached to mouth. The electrodes are placed on (zygomaticus minor and major) and on occipitofrontal and orbicularis muscles present in the mouth. The type of emotion detected by this method includes happiness, sadness, indifference and pain [30]. The disadvantages of this method include inhibition of facial movements and double meaning of certain expressions [31]. 


\section{Cardiovascular Parameters}

Variations in cardiovascular parameters such as heart beat rate and blood pressure fluctuations can also be used to detect the consumer's response to product and product advertisements. Pulse transition time and patterns of heart beats can detect attention span of a customer on a particular [32].

\section{Galvanic Skin Response}

Several human emotions such as happiness, fear, anger, interest, anxiety, indifference create recordable stimulus on an individual's hand. The stimulus created on human hands by neural response can be measured and the information can be used in marketing [33].

\section{The Transcranial Magnetic Stimulation (TMS)}

The basic principle of Transcranial Magnetic Stimulation is modulating cortical activity by electromagnetic induction. The Transcranial magnetic stimulation uses two types of electric impulses namely low and high frequency. This technique can perform temporary activation and deactivation of a cortical area of interest. The limitation with this approach is that it cannot penetrate beyond the neocortex with this method [34].

\section{Understanding the Consumers Brain}

The primary aim of any market research study is to understand the impact and reach of a product in the market through advertisements. For a longer period, conventional techniques have failed miserably. Market researchers have depended solely upon feedback through interviews and survey from a focus group to know about the success of a product advertisement. The arrival of neuroimaging techniques has offered novel exciting methodological alternatives. Neuromarketing tools are primarily used to identify the impact created by an advertisement on a customer at a subconscious level. This will enable them to accurately predict the success and failure of an advertisement.

\section{Practical Applications of Neuromarketing}

Neuromarketing is primarily used to identify consumers' preferences. An important thrust area in marketing is the process of delivery of information about a product and its relevance to the customer [35,36]. A well-established psychological fact in marketing is physical and emotional attraction in advertisements creates and builds trust and recognition. This in turn will influence the consumers' preferences and purchasing decision. Comforting and soothing emotions generated by advertisements creates a sense of identification and activate reward areas in the brain of the customer [13]. Neuromarketing enables advertising companies to identify subsections of advertisements such as sound effect, images, and slogans for producing effective advertisements. The consumer choices and preferences can be better assessed before creating an advertisement [11].

\section{Benefits of Neuromarketing}

Companies are benefitted by neuromarketing as it creates better understanding of the consumers brain and decipher its decision-making process $[5,10,13,37]$. By using neuromarketing methods, effective consumer groups and cohorts can be identified. The cohorts can be demarcated based upon age, sex, ethnicity, locality and socioeconomic constraints. This will lead to better judgement of consumer behaviour and target specific marketing [38]. The various examples of neuromarketing and their mode of action are given in Table 1.

Table 1: The various examples of neuromarketing strategies, mode of action and their prospective effect on customers.

\begin{tabular}{|c|c|c|c|}
\hline S.NO & Strategy & Mode of Action & Effect on Customers \\
\hline \multirow{3}{*}{1} & \multirow{3}{*}{$\begin{array}{l}\text { Using Sound and colour to sell } \\
\text { product }\end{array}$} & \multirow{3}{*}{$\begin{array}{l}\text { Immediate impact on the human } \\
\text { brain }\end{array}$} & $\begin{array}{l}\text { Powerful bass makes people subconsciously attend to dark } \\
\text { objects. }\end{array}$ \\
\hline & & & $\begin{array}{l}\text { Music leaning more towards the high frequencies shifts } \\
\text { attention to light objects. }\end{array}$ \\
\hline & & & White colour attracts more when compared to black colour. \\
\hline \multirow[b]{2}{*}{2} & \multirow{2}{*}{$\begin{array}{l}\text { The most persuasive way is to } \\
\text { frame scarcity in advertisements }\end{array}$} & \multirow{2}{*}{$\begin{array}{l}\text { Influencing people through } \\
\text { advertisements }\end{array}$} & $\begin{array}{l}\text { Gain frames are sentences like: "get the new edition now", } \\
\text { while loss frames are sentences like "be sure not to miss the } \\
\text { new edition". }\end{array}$ \\
\hline & & & $\begin{array}{l}\text { People with a high need for uniqueness prefer to hear } \\
\text { what they will miss when they don't buy the product, while } \\
\text { people with low need for uniqueness need to hear what } \\
\text { there is to gain from buying it. }\end{array}$ \\
\hline \multirow[t]{2}{*}{3} & \multirow{2}{*}{$\begin{array}{l}\text { Using subtle rewards to influence } \\
\text { consumers online. }\end{array}$} & \multirow{2}{*}{$\begin{array}{l}\text { Rewarding customers is a great way } \\
\text { to keep them coming back }\end{array}$} & $\begin{array}{l}\text { Shops focus on delayed rewards, like a certain amount of } \\
\text { points which each purchase that can be converted into shop } \\
\text { credit at a later point. }\end{array}$ \\
\hline & & & $\begin{array}{l}\text { Short term rewards help people stay on track during the } \\
\text { time they need to reach long term goals. }\end{array}$ \\
\hline \multirow{2}{*}{4} & \multirow{2}{*}{$\begin{array}{l}\text { Creating an efficient product design } \\
\text { process. }\end{array}$} & \multirow{2}{*}{$\begin{array}{l}\text { Offering the best and unique } \\
\text { packaging options. }\end{array}$} & Comparison of different packaging options for things. \\
\hline & & & $\begin{array}{l}\text { Volvo and Hyundai have used similar methods to figure out } \\
\text { which elements of new car models spoke to consumers. }\end{array}$ \\
\hline
\end{tabular}




\begin{tabular}{|c|c|c|c|}
\hline & & & $\begin{array}{c}\text { Successful brands engage consumers in multi-sensory } \\
\text { stimulation. }\end{array}$ \\
\cline { 3 - 4 } & Creating a multi-sensory mismatch. & $\begin{array}{c}\text { Products and packaging that makes } \\
\text { material looks like something else. }\end{array}$ & $\begin{array}{c}\text { This means that they offer a brand experience on more than } \\
\text { just visual aspects alone, like smell and taste. If two sensory } \\
\text { cues don't match, it's considered a mismatch. }\end{array}$ \\
\hline 6 & $\begin{array}{c}\text { Predicting future successes with } \\
\text { neuroscience. }\end{array}$ & $\begin{array}{c}\text { Influencing the market success of a } \\
\text { product. }\end{array}$ & $\begin{array}{c}\text { Influences market investment, time management, man and } \\
\text { money power management }\end{array}$ \\
\hline
\end{tabular}

\section{Advantages of Neuromarketing}

Neuromarketing is a marketing application of behavioural neurosciences. The tools of neuromarketing identify stimuli and cues revealing customer behaviour not detected by careful visual observation [38]. Neuromarketing techniques help in product design, brand creation and effective advertisements [39]. They help to understand the overall shopping experience of a customer from the moment they step into a market and until they leave, apart from the neural response at the time of purchase. An interesting application is virtual store that has $2 \mathrm{D}$ and $3 \mathrm{D}$ retail products that creates a real store shopping experience. Test customers are given real marketing experience and their purchase making decisions analysed effectively.

\section{Limitations of Neuromarketing}

Neuromarketing also suffers from severe handicaps and limitations. An Important drawback of neuromarketing is the absence of credibility and trustworthiness of the information $[2,4,8,11,13,15,40]$. Recently the term neuroscience is much popular in several fields of knowledge. Very few publications done by neuromarketing companies and academics are currently available $[4,17,15,42]$. Further the findings published by companies or marketing researchers can also be biased or influenced $[2,43]$. The moment and the situation of the marketing stimuli received by an individual can also result in differential processing of the stimuli $[11,42]$. The concept of emotions and their association with certain brain areas is a debatable concept $[10,16]$. A key limitation of neuromarketing is the difficulty of designing new experiments, the high cost and time factor.

\section{Neuromarketing on Consumer Buying Behaviour}

The increasing number of products in the market makes the in-depth analysis of consumer buying behaviour highly desirable and advantageous $[16,44]$. The human brain conceals information of true desires and needs that influences buying decisions. Any knowledge of consumer decision making negates the cost of neuromarketing in comparison to the information delivered [5]. The information gleaned by the various tools of neuromarketing can be effectively used for the designing of new products that can alter the consumer buying behaviour [26].

\section{Neuromarketing on Advertising}

Advertisements activate specific regions of the brain. The regions of brain activated by effective advertisements include ventromedial prefrontal cortex and ventral striatum [7]. The study affirmatively identified the impact of positive facial expressions in advertisements [7]. The response and success of an advertisement can be accurately measured at an individual level by the neuromarketing tools. Advertisements can modify the medial prefrontal cortex decision making region of the brain that can increase the sales [45].

\section{Neuromarketing on Pricing}

The price of the product is an important factor that can potentially influence a customer purchasing decisions [42]. An important aspect of purchasing decision is fixing the ideal price for a service or product [46]. Fixing the price of a product and its association with purchase making decision of a customer is the trickiest part in marketing $[47,48]$. Neuromarketing can help the marketers to find the amount fixed for a product or a service on the mind of the customers. This will enable the marketers to adjust the prices of the product accordingly. Appropriate brain scanning techniques can be used to find regions of the brain activated by pain or happiness.

\section{Neuromarketing on New Product Development}

Neuromarketing tools are considered more appropriate for analysing the product experience and not the conception and development of a new product [5]. Since no valid inputs can be obtained for the development of new product alternate methods can be used. In contrary some studies also suggest that the internal information disclosed form fMRI scan data can be used for pretesting and development of new products [49]. Hence neuromarketing can be used effectively for product testing and new product development. Along with neuromarketing, SWOT analysis (Strengths, Weaknesses, Opportunities and Threats) can also be used for new product development.

\section{Neuromarketing on Communication}

Verbal communication expressed by the consumer will not be influenced by neuromarketing measurements since logically it can be analysed by the conventional methods of market research. Body language and facial expressions is analysed by outside reflex neuromarketing techniques [19]. However, the most accurate is the inside reflex measurements such as fMRI or EEG. Hence neuromarketing techniques will not be of great use in communication and scarce or no available literature is available in this regard.

\section{Neuromarketing on Distribution of Products}

Neuromarketing techniques can be used to make efficient distribution, arrangement and display of products in the shelves and racks of supermarkets. Neuromarketing techniques can be used to identify the ideal and effective arrangement pattern of products for attracting customers attention [50]. An important case of decision making is the top-shelf example. Products on the top shelves of the stores are more evaluated by the customers 
[51]. Products in the top shelves usually get more attraction from the customers [52]. Eye tracking and caps attached with EEG on customers head performing shopping can be used for studying the behaviour of shoppers [53]. Online shops can also be analysed by this method [54].

\section{Neuromarketing on Decision-Making}

Decision making in neuromarketing has five different stages. This include: identifying the problem, weighing the possible choices, decision after evaluation of the available choices, considering the possible consequences of decisions, learning for the future from decision making process [55]. The decision-making process analysed by fMRI neuromarketing technique is a culmination of emotions [56]. The decision-making process analysed by fMRI and EEG shows the involvement of ventromedial prefrontal cortex and striatum brain regions [57]. The consumer decision making process can also be manipulated to a certain extent $[58,59]$.

\section{Neuromarketing on Branding}

Customers normally prefer to attach loyalty to their preferred brands. Brands usually create emotional attachment and bonding that influence customer decisions [60]. This shows the importance of brand attachment and the opportunity should be rightly used by the marketers. fMRI studies have shown increased brain activity in preferred brands than common brands [7,13,61-63]. Brands have created an intuitive and hidden apprehension that have an effect upon the decision-making process on a product [13]. Table 2 shows the successful use of neuromarketing strategies by the successful brands.

Table 2: Some prominent companies that use neuromarketing and their purpose.

\begin{tabular}{|c|c|c|}
\hline Company & Industry & Purpose of Neuromarketing \\
\hline GMTV & Television & $\begin{array}{c}\text { Conduct a study to teach advertisers how viewer's brains act during } \\
\text { morning hours. }\end{array}$ \\
\hline VIACOM & Media & Study reactions to advertising. \\
\hline HAKUHODO & Advertising & $\begin{array}{c}\text { Observe responses to products, brands, advertising and video } \\
\text { content. }\end{array}$ \\
\hline PHD & Media Planning & Measure the relative effectiveness of advertising. \\
\hline Martin Lindstrom (Neurosense) & Author & $\begin{array}{l}\text { Neurosense designed and analyzed all the fMRI studies used for } \\
\text { Lindstrom's book research. }\end{array}$ \\
\hline Yahoo & Media & Study consumer's reaction to a television commercial. \\
\hline Hyundai & Automotive & Study consumer's reaction when viewing a sport's car. \\
\hline Microsoft & Technology \software & $\begin{array}{l}\text { Understanding consumer's interaction with computers including } \\
\text { their feelings of surprise, satisfaction and frustration. }\end{array}$ \\
\hline Ebay & Online auctions & Adopted ad campaign on the basis of neuromarketing research. \\
\hline Frito-Lay & Food & $\begin{array}{c}\text { Adjusted commercials, products and packaging on the basis of } \\
\text { neuromarketing based research. }\end{array}$ \\
\hline $\begin{array}{l}\text { Neurofocus (Conducted } \\
\text { neuromarketing research for among } \\
\text { others Google, Chevron and Walt } \\
\text { Disney company) }\end{array}$ & Neuromarketing research & Consulting based neuromarketing research \\
\hline The weather channel & Television & Study viewers reactions to promotions \\
\hline Daimler Automotive & Automotive & Study consumers reaction to car headlight characteristics \\
\hline Pepsico & Food & idea for single-serve packaging and corresponding ad campaign \\
\hline Porsche & Automotive & Consumer response to advertisement \\
\hline Facebook & Social Networking & frequently a page should post, how to plan out an ad campaign \\
\hline Coca Cola & Food & Effective advertisement of product \\
\hline PayPal & Money transfer & Advertisement emphasising speed and convenience \\
\hline Volvo & Automotive & Study related to car designing. \\
\hline Microsoft & Software & $\begin{array}{l}\text { Eye tracking and EEG measures to analyse the brain's response to the } \\
\text { various content, aesthetics and web design combinations }\end{array}$ \\
\hline Budweiser & Food & Study positive emotional response in advertisement \\
\hline
\end{tabular}

\section{Neuromarketing on Product Design}

Product design and presentation is important feature of marketing and market research Hence the product design and presentation aspect should be given sufficient attention to minute details. Neuromarketing tools like fMRI and EEG can help in better design of products [44]. Since the entire process takes place subconsciously in the brain it is highly reliable. The nucleus accumbens and ventromedial pre-frontal cortex region of the brain are associated with the process of decision making [64].

\section{Ethical Issue of Neuromarketing}

Several ethical concerns should be addressed during the course of research methods and approaches of neuromarketing. Some are of the opinion that neuromarketing is against the idea of free 
will. Marketers are aware of the central idea that the availability of several product in the market empowers the decision-making process of the customers. In this regard the technology of neuromarketing is infringing on the rights to make individual choices [26]. This increases the thrust area of marketing towards commercial gain and diminishes the idea of catering to the needs of the customers [22]. This is against the idea of a customer-company relationship that comprises privacy policy issues [65]. The skewing of the decision-making process of the brain by the use of brain probes clearly violates the rights and creates ethical concerns and hence rules and regulations are needed in this regard $[4,10]$. Two crucial ethical issues concerning neuromarketing is the protection of the individual affected by research on neuromarketing and the other is the protection of the free will of the customer in decision making [40]. Hence industry standards and regulations need to be introduced to prevent misuse and responsible use of the techniques of neuromarketing for enhancing the consumer shopping experience [5,66]. Even though the rewards of neuromarketing are huge there are still several grey areas neuromarketing needs to address with regards to ethical concerns and customer friendly atmosphere.

\section{Challenges of Neuromarketing}

No marketing strategy can completely eliminate or block the decision-making process of a customer [22]. There are also several apprehensions about neuromarketing. Using a technology in market research is not harmful but some see that it can create a buy button effect that can completely eliminate the free will of the customers. It will completely eliminate the rational thinking of the customer and create human robots that are programmed to react to marketing stimulus. In other wards humans can be converted into programmed buying machines intended to consume predetermined products and product choices $[7,26,42]$. Neuromarketing is rapidly getting the attention of the companies and more are using its services [7,67-71].

\section{Future of Neuromarketing in India}

The future prospects of the emerging field of neuromarketing in India are very bright. According to the Boston consultancy group from 2016 to 2025 the share of the affluent and elite in the five household income categories in India will increase from 8 percent to 16 percent whereas the share of the strugglers will drop from 31 to $16 \%$. The elite and affluent categories will account for $40 \%$ as against the current $27 \%$. India with a huge population of more than 130 billion people is likely to emerge as the biggest consumer market in the world overtaking china in the near future. Consumer Price Index CPI in India averaged 114.67 Index Points from 2011 until 2017, reaching an all-time high of 137.60 Index Points in November of 2017. The current 2.8 trillion \$ GDP (2018) at the growth rate of around $7 \%$ is expected to reach 4.6 trillion $\$$ by 2025 (Table 3). For example, the consumer electronics market size was USD 14 billion in 2015 and is expected to be USD 29 billion by 2020 (Figure 4) and the Indian advertising market is estimated to be about 693 billion rupees in 2018 (Table 4). All the above indicators point to a trend of increase in consumer expenditure, introduction of new products and market competition. In this context neuromarketing is the most preferred tool for market researchers to gauge the consumer behaviour and mind-set.

Table 3: Comparison of the past and future projected economic sizes of USA, China and India in nominal \& PPP scale.

\begin{tabular}{|c|c|c|c|c|c|c|}
\hline S.No & Country & $\mathbf{2 0 1 0}$ & $\mathbf{2 0 1 5}$ & $\mathbf{2 0 1 8}$ & $\mathbf{2 0 2 3}$ & $\mathbf{2 0 3 0}$ \\
\hline 1 & USA & 14,964 & 18,120 & 20,412 & 24,537 & 32,996 \\
\hline 2 & China & 6,066 & 11,226 & 14,092 & 21,574 & 34,338 \\
\hline 3 & India & 1,708 & 2,089 & 2,848 & 4,663 & 10,133 \\
\hline
\end{tabular}

Note: The past and projected GDP of the economies of USA, China and India on the Nominal scale from 2010 - 2050 in US Dollars (billions).

\begin{tabular}{|c|c|c|c|c|c|c|}
\hline S.No & Country & $\mathbf{2 0 1 0}$ & $\mathbf{2 0 1 5}$ & $\mathbf{2 0 1 8}$ & $\mathbf{2 0 2 3}$ & $\mathbf{2 0 3 0}$ \\
\hline 1 & USA & 14,964 & 18,036 & 20,412 & 24,537 & 30,998 \\
\hline 2 & China & 12,405 & 19,695 & 25,238 & 37,067 & 54,366 \\
\hline 3 & India & 5,312 & 8,003 & 10,385 & 16,785 & 26,526 \\
\hline
\end{tabular}

Note: The past and projected GDP of the economies of USA, China and India on the Purchasing Power parity (PPP) scale from 2010 - 2050 in US Dollars (billions).

Table 4: Indian advertising expenditure across the various media in billion rupees.

\begin{tabular}{|c|c|c|c|c|c|}
\hline Medium & $2017 F$ & Adex global ranking 2017 & $2018 F$ & Adex global ranking 2018 & $18 \mathrm{~F}$ VS 17F \\
\hline TV & 279.61 & 9 & 315.96 & 8 & $13 \%$ \\
\hline Print & 177.79 & 5 & 184.37 & 4 & $4 \%$ \\
\hline Digital & 94.9 & 15 & 123.37 & 15 & $30 \%$ \\
\hline $\mathrm{OOH}$ (Out of Home) & 29.42 & 11 & 33.89 & 11 & $15 \%$ \\
\hline Radio & 24.19 & 13 & 27.82 & 13 & $15 \%$ \\
\hline Cinema & 6.72 & & 8.06 & & $20 \%$ \\
\hline Total & 612.63 & & 693.47 & & $13 \%$ \\
\hline
\end{tabular}




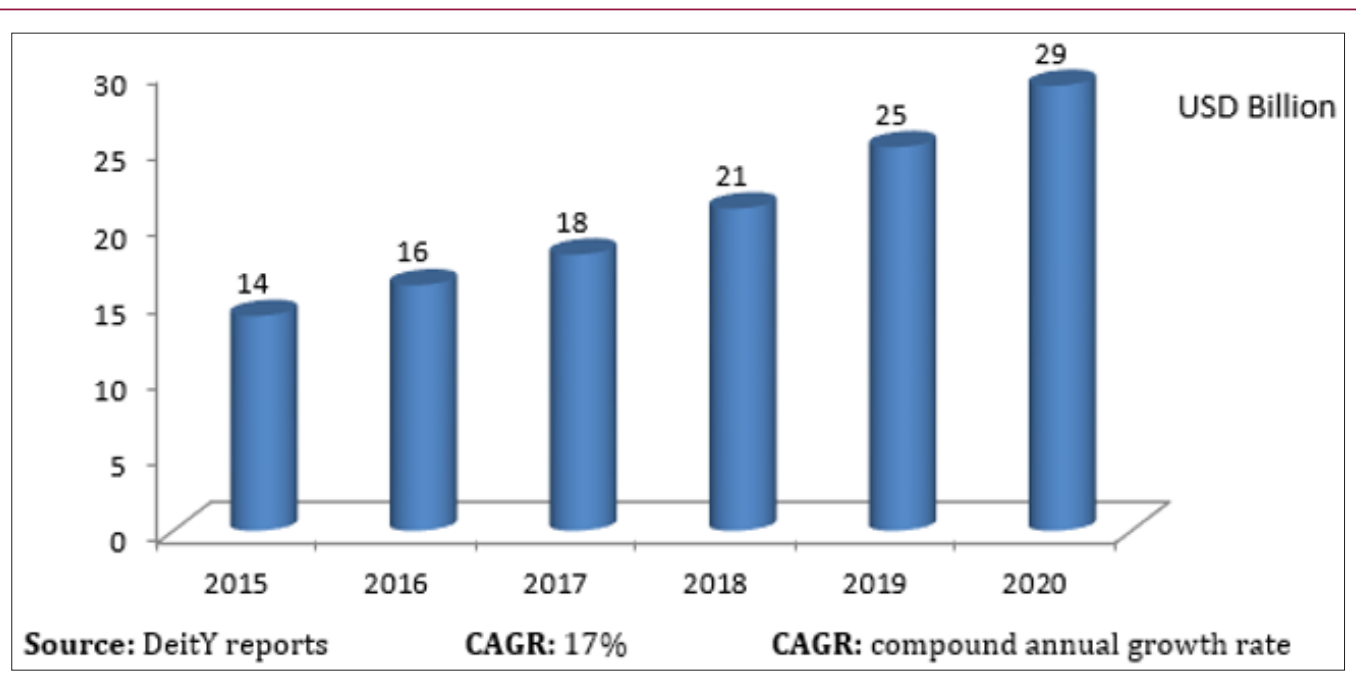

Figure 4: The size of the consumer electronic market size in India over a period of six years.

\section{Conclusion}

Neuromarketing offers exciting opportunities and provides new avenues to explore in the field of marketing. Neuromarketing strategies are at a very early stage and promises much more in the future [42]. There is a wide consensus among neuromarketing researchers that the field has to go a long way and cross several hurdles before it can emerge as a prominent tool in the field of market research. Nonetheless neuromarketing creates more interests and is expected to play a pivotal role in the highly competitive domain of global marketing. With the increasing availability of high end technology and gadgets neuromarketing is bound to gain more in the longer run.

\section{References}

1. Karmarkar, Uma R (2011) Note on Neuromarketing. Harvard business school background Note 512-031.

2. Javor A, Koller M, Lee N, Chamberlain L, Ransmayr G (2013) Neuromarketing and consumer neuroscience: Contributions to neurology. BMC Neurology 13(1): 1-12.

3. Schneider T, Woolgar S (2012) Technologies of ironic revelation: Enacting consumers in neuromarkets. Consumption Markets \& Culture 15(2): 169-189.

4. Eser Z, Isin FB, Tolon M (2011) Perceptions of marketing academics, neurologists and marketing professionals about neuromarketing. Journal of Marketing Management 27(7-8): 854-868.

5. Ariely D, Berns GS (2010) Neuromarketing: The hope and hype of neuroimaging in business. Nat Rev Neurosci 11(4): 284-292.

6. Calvert GA, Thensen T (2004) Multisensory integration: Methodological approaches and emerging principles in the human brain. J Physoil 98(13): 191-205.

7. Kenning P, Linzmajer M (2011) Consumer neuroscience: An overview of an emerging discipline with implications for consumer policy. Journal für Verbraucherschutz und Lebensmittelsicherheit 6(1): 111-125.

8. Morin C (2011) Neuromarketing: The new science of consumer behaviour. Society 48(2): 131-135.

9. Pradeep AK (2010) The buying brain: Secrets for selling to the subconscious mind. John Wiley \& Sons.

10. Senior C, Lee N (2008) Editorial: A manifesto for neuromarketing science. J Consumer Behav 7(4-5): 263-271.
11. Fugate DL (2007) Neuromarketing: A layman's look at neuroscience and its potential application to marketing practice. Journal of Consumer Marketing 24(7): 385-394.

12. Ohme R, Matukin M (2012) A small frog that makes a big difference: Brain wave testing of TV advertisements. IEEE Pulse 3(3): 28-33.

13. Hubert M, Kenning $P$ (2008) A current overview of consumer neuroscience. J Consumer Behav 7(4-5): 272-292.

14. Garcia JR, Saad G (2008) Evolutionary neuromarketing: Darwinizing the neuroimaging paradigm for consumer behaviour. J Consumer Behav 7(4-5): 397-414.

15. Fisher CE, Chin L, Klitzman R (2010) Defining neuromarketing: Practices and professional challenges. Harvard Review of Psychiatry 18(4): 230237.

16. Butler MJ (2008) Neuromarketing and the perception of knowledge. J Consumer Behav 7(4-5): 415-419.

17. Fugate DL (2008) Marketing services more effectively with neuromarketing research: A look into the future. Journal of Services Marketing 22(2): 170-173.

18. Orzán G, Zara IA, Purcarea VL (2012) Neuromarketing techniques in pharmaceutical drugs advertising. A discussion and agenda for future research. J Med Life 5(4): 428-432.

19. Postma (2012) Anatomy of the Temptation. Neuromarketing Neuromarketing successful to fit.

20. Leonard D, Rayport JF (1997) Spark innovation through empathic design. Harvard business review 75: 102-115.

21. Camerer C, Loewenstein G, Prelec D (2005) Neuroeconomics: How neuroscience can inform economics. Journal of economic Literature 43(1): 9-64.

22. Madan CR (2010) Neuromarketing: The next step in market research? Eureka 1(1): 34-42.

23. Dimoka A, Banker RD, Benbasat I, Davis FD, Dennis AR, et al. (2012) On the use of neurophysiological tools in IS research: Developing a research agenda for neurois. MIS Quarterly 36(3): 679-702.

24. Vecchiato G, Kong W, Maglione A, Wei D (2012) Understanding the impact of TV commercials: Electrical neuroimaging. IEEE Pulse 3(3): 42-47.

25. Raichle ME, Mintun MA (2006) Brain work and brain imaging. Ann Rev Neurosci 29: 449-476.

26. Wilson R, Gaines J, Hill RP (2008) Neuromarketing and consumer free will. Journal of Consumer Affairs 42(3): 389-410. 
27. Miller M, Bentsen T, Clendenning DD, Harris S, Speert D (2008) Brain facts: A primer on the brain and nervous system, $\left(6^{\text {th }}\right.$ edn $)$. Society for Neuroscience, Washington.

28. Lin C H, Tuan HP, Chiu YC (2010) Medial frontal activity in brandloyal consumers: A behaviour and near-infrared ray study. Journal of Neuroscience, Psychology and Economics 3(2): 59-73.

29. Nenad DH (2011) Emotional marketing: Eye-tracking and brain measuring: Using neuromarketing to sell newspapers. Editor \& Publisher 144(1).

30. Melillo W (2006) Inside the consumer mind: What neuroscience can tell us about marketing. Adweek 47(3).

31. CK Peterson (2009) Electroencephalographic Methods in social and personality psychology. In: Harmon-Jones E, Jennifer SB (Eds.), Methods in Social neuroscience. TG Press, Guilford Publications, New York, USA, pp. 170-197.

32. Lindstrom M (2010) Buyology: Truth and lies about why we buy. Random House Digital.

33. Banks SJ, Bellerose J, Douglas D, Jones-Gotman M (2012) Bilateral skin conductance responses to emotional faces. Appl Psychophysiol Biofeedback 37(3): 145-152.

34. Zurawicki L (2010) Neuromarketing: Exploring the brain of the consumer. Springer-Verlag Berlin Heidelberg, New York, USA.

35. Lee NJ, Senior C, Butler MJ, Fuchs R (2009) The feasibility of neuroimaging methods in marketing research. Nature precedings.

36. Fisher CE, Chin L, Klitzman R (2010) Defining neuromarketing: Practices and professional challenges. Harv Rev Psychiatry 18(4): 230-237.

37. Tusche A, Bode S, Haynes JD (2010) Neural responses to unattended products predict later consumer choices. J Neurosci 30(23): 8024-8031.

38. Venkatraman V, Clithero JA, Fitzsimons GJ, Huettel SA (2012) New scanner data for brand marketers: How neuroscience can help better understand differences in brand preferences. J Consumer Psycho 22(1): 143-153.

39. Belden SRA (2008) Science is Culture: Neuroeconomics and neuromarketing. Practical applications and ethical concerns. J Mind Theory (1).

40. Murphy ER, Illes J, Reiner PB (2008) Neuroethics of neuromarketing. J Consumer Behav 7(4-5): 293-302.

41. Perrachione TK, Perrachione JR (2008) Brains and brands: Developing mutually informative research in neuroscience and marketing. J Consumer Behav 7(4-5): 303-318.

42. Lee N, Broderick AJ, Chamberlain L (2007) What is 'neuromarketing'? A discussion and agenda for future research. Int J Psychophysiol 63(2): 199-204.

43. Marci CD (2008) Minding the gap: The evolving relationships between affective neuroscience and advertising research. International Journal of Advertising 27(3): 473-475.

44. Gang DJ, Lin W, Qi Z, Yan LL (2012) Neuromarketing: Marketing through Science. International Joint Conference 285-289.

45. Cranston RE (2004) Neuromarketing: Unethical advertising? The Centre for Bioethics and human Dignity.

46. Simon H, Dolan RJ (1998) Price Customization. Marketing Management 7(3): 11-17.

47. Vanhuele M, Drèze X (2002) Measuring the price knowledge shoppers bring to the store. Journal of Marketing 66(4): 72-85.

48. Evanschitzky H, Kenning P, Vogel V (2004) Consumer price knowledge in the German retail market. Journal of Product and Brand Management 13(6): 390-405.

49. Calvert GA, Brammer MJ (2012) Predicting consumer behaviour: Using novel mind-reading approaches. IEEE Pulse 3(3): 38-41.
50. Ailawadi KL, Keller KL (2004) Understanding retail branding: Conceptual insights and research priorities. Journal of Retailing 80(4): 331-342.

51. Chandon P, Hutchinson JW, Bradlow ET, Young SH (2009) Does in-store marketing work? Effects of the number and position of shelf facings on brand attention and evaluation at the point of purchase. Journal of Marketing 73(6): 1-17.

52. Pieters R, Warlop L (1999) Visual attention during brand choice: The impact of time pressure and task motivation. International Journal of Research in Marketing 16(1): 1-16.

53. Plassmann H, Ramsøy TZ, Milosavljevic M (2012) Branding the brain: A critical review and outlook. Journal of Consumer Psychology 22(1): 18-36.

54. Dreze X, Hussherr FX (2003) Internet advertising: Is anybody watching? Journal of Interactive Marketing 17(4): 8-23.

55. Rangel A, Camerer C, Montague PR (2008) A framework for studying the neurobiology of value- based decision making. Nature Reviews Neuroscience 9(7): 545-556.

56. Plassmann H, Ramsøy TZ, Milosavljevic M (2012) Branding the brain: A critical review and outlook. J Consumer Psychol 22(1): 18-36.

57. Peelen MV, Li FF, Kastner S (2009) Neural mechanisms of rapid natural scene categorization in human visual cortex. Nature 460: 94-97.

58. Vohs KD, Schooler JW (2008) The value of believing in free will: Encouraging a belief in determinism increases cheating. Psychol Sci 19(6): 49-54.

59. Montague R (2008) Free will. Current Biology 18(4): 584-585.

60. Bechara A, Damasio AR (2005) The somatic marker hypothesis: A neural theory of economic decision. Games and Economic Behaviour 52(2): 336-372.

61. McClure SM, Li J, Tomlin D, Cypert KS, Montague LM, et al. (2004) Neural correlates of behavioural preference for culturally familiar drinks. Neuron 44(2): 379-387.

62. Schaefer M, Berens H, Heinze H, Rotte M (2006) Neural correlates of culturally familiar brands of car manufacturers. Neuroimage 31(2): 861865.

63. Walter H, Abler B, Ciaramidaro A, Erk S (2005) Motivating forces of human actions: Neuroimaging reward and social interaction. Brain Res Bull 67: 368-381.

64. Reimann M, Zaichkowsky J, Neuhaus C, Bender T, Weber B (2010) Aesthetic package design: A behavioral, neural and psychological investigation. J Consumer Psychol 20(4): 431-441.

65. Illes J, Racine E (2005) Imaging or imagining? A neuroethics challenge informed by genetics. Am J Bioeth 5(2): 5-18.

66. Kumlehn M (2011) Consumer Neuroscience: Pricing research to gain and sustain a cutting edge competitive advantage by improving customer value and profitability. SSRN p. 83.

67. Reid A (2006) MRI scanners can improve advertising effectiveness. Campaign.

68. Page G (2012) Scientific realism: What 'Neuromarketing' can and can't tell us about consumers. International Journal of Market Research 54(2): 287-290.

69. Kotler P, Keller KL (2006) Marketing Management. Prentice-Hall International, New Jersey, USA.

70. Flores, Jason, Arne B, Robert S (2014). Is Neuromarketing Ethical? Consumers Say Yes. Consumers Say No. Journal of Legal, Ethical and Regulatory Issues 17(2): 77-91.

71. Calvert GA, Brammer MJ (2012) Predicting consumer behaviour: Using novel mind-reading approaches. IEEE Pulse 3(3): 38-41. 
ISSN: 2574-1241

DOI: $10.26717 / B J S T R .2018 .12 .002230$

Pravin Raj Solomon. Biomed J Sci \& Tech Res

cC) (i) This work is licensed under Creative

Submission Link: https://biomedres.us/submit-manuscript.php

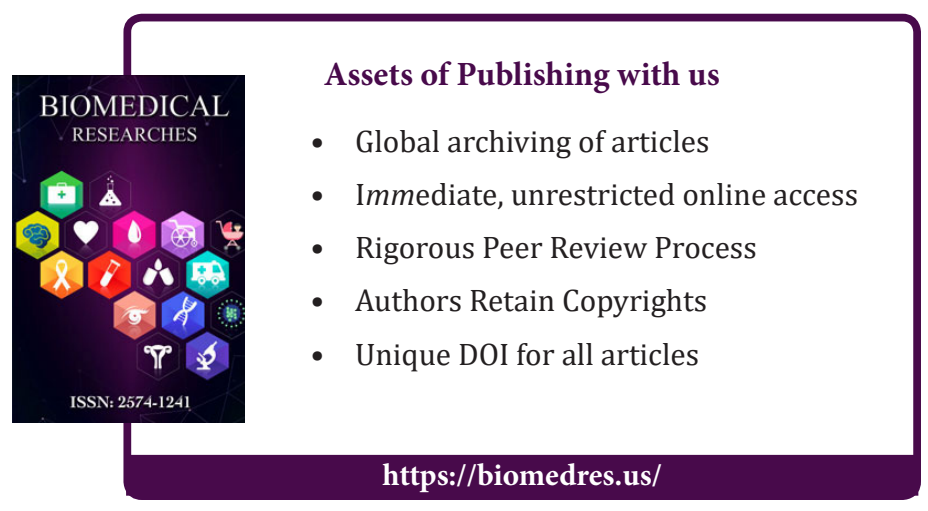

